\title{
USING GAMES TO IMPROVE STUDENTS' ACTIVE INVOLVEMENT IN THE LEARNING OF ENGLISH SYNTAX AT IAIN MADURA: AN AUTONOMOUS LEARNING
}

\author{
Abdul Wafi \\ (IAIN Madura/wafizain1234@gmail.com)
}

\begin{abstract}
Learning English syntax is taken as a boring subject for the majority of students since the activities frequently monotonous and the classroom setting becomes quiet and too formal. The study is intended to discover the use of games in the learning of English syntax. It is conducted to find out whether the games provided by students themselves (autonomously) are able to make a joyful learning activities and able to increase their involvement in the learning process. The study makes use descriptive research which is classified into a case study. The data are collected through classroom observation, questionnaire to gain students' response toward the classroom learning activities. The research subjects are the students of 5th semester at English department IAIN Madura who join in English syntax class. The researcher focuses on D class, with 33 students, where the time schedule for the learning is at 13.00 in the afternoon. From the data result, it is found that the use of games, which are prepared by the students autonomously, is able to make the class more joyful and able to increase their active involvement in the learning activities. Making this study distinctive from other studies is the games are provided by the students themselves instead of being provided by the lecturer. So, learning autonomy is really there. The lecturer only gives them a clear rule that is the learning activities should be made joyful by using any games related to the topic being discussed.
\end{abstract}

Keywords:

Games; autonomous learning; active involvement

DOI: $10.19105 /$ ojbs.v13i1.2256

\section{A. Introduction}

When English syntax was first introduced to students and a questionnaire was also distributed to them questioning whether the learning English Syntax is boring or not, it appeared various responses but getting bored and getting serious and monotonous activities were very common for them. Indeed, students felt bored when they joined English syntax class. The classroom became quiet and the learning activities became really serious that enabled the students to get bored and lazy. The class was getting more awful when the learning was conducted at midday or in the afternoon. Knowing that midday is lazy time for studying and afternoon is going to be the final class session of the day.

English syntax is discussing the system of rules and categories that 
allows words to be combined to form sentences. ${ }^{1}$ It is said that a sentence might be taken as grammatically correct or incorrect based on its syntactical rules. It is not syntactically allowed to form utterances by randomly combining any lexical categories. To be grammatically correct, it is highly suggested to learn the patterns and rules.

Teaching English syntax at IAIN Madura is conducted in the $5^{\text {th }}$ semester. It is given as to provide the students with the knowledge of syntactic theory and analysis that they are able to understand and comprehend the concept of syntax as the patterns of sentences. There are 6 classes of English syntax however the researcher, who is also as lecturer, teaches in 3 classes only namely $D$ class, E class and F class. There are 33 students of each class with the time schedule on Friday at 3pm for D class, Saturday at $1 \mathrm{pm}$ for $\mathrm{E}$ class and $3 \mathrm{Pm}$ for $F$ class. The researcher focuses his research in $\mathrm{E}$ class due to the learning time at $1 \mathrm{Pm}$ which is believed as the most challenging time to conduct the learning activities.

The learning activities are generally divided into two sections; they are the learning activities before middle test and the learning activities after middle test. Before middle test, the learning activities are handled by the researcher in the form of lecturing and

1 William O'Grady and Michael Dobrovolsky, Contemporary Linguistics: An Introduction (New York: St. Martin's Press, 1989), 126. drill given. After the middle test, the learning activities are autonomously handled by the students in the form of group presentation. Each group is obliged to present each topic by really considering to a joyful learning. Each group is suggested to make use games in the presentation.

Using games in the learning provides ample benefits. Philips in Dwiaryanti $^{2}$ states that playing game in the classroom develops the ability to cooperate, to complete without being aggressive and to be a good looser. Furthermore, Sultanova ${ }^{3}$ elaborates the benefits of using game in language learning are that (1) the use of games are able to decrease then students' anxious feeling, (2) games are highly encouraging and entertaining and they enable to give shy students more chances to express their ideas and feelings, (3) games are also able to help the learners to acquire new experience within the foreign language that are not always possible during a typical lesson, (4) games may increase diversion to the regular classroom activities, break the ice and introduce the new ideas, (5) games are able to increase the students retention through relaxed atmosphere in the games, (6) grammar games are a good way of practicing the language

\footnotetext{
2 Risca Dwiaryanti, 'Learning Vocabulary through Colourful Puzzle Game', OKARA: Jurnal Bahasa Dan Sastra 8, no. 1 (2014): 138-39.

${ }^{3}$ Sultanova D.T., 'The Use of Games in Learning English Grammar', in Proceeding of UzbekIndonesian Joint International Conference, vol. 1 (Gunadarma University, 2011), https://core.ac.uk/download/pdf/143964197.pdf.
} 
because they provide a model of what learners will use the language for in future real life, and (7) grammar games are also able to encourage, entertain, teach and promote fluency.

Ample studies have been conducted in regarding to the use of games in language learning. Phuong and Nguyen conducted experimental research toward fifty adult Vietnamese $E F L$ learners on the impact of board games to their grammar retention and the study reveals that board games had significant effects on EFL learners' grammar retention and learners had positive attitudes towards the use of board games in grammar classes. ${ }^{4}$ Ramadhaniarti conducted a research at SMPN 14 Kota Bengkulu to find out the students' view on the use of games in the teaching English vocabulary. ${ }^{5}$ The result shows that the students give positive view on the use of games in the teaching. It said that playing games is fun, more interesting and challenging. Using games is one effective and interesting way that can be applied in any classrooms. Game is really avoiding the students from being bored in their usual classes where they sit passively.

\footnotetext{
4 Hoang Yen Phuong and Thao Nguyen Pham Nguyen, 'The Impact of Board Games on EFL Learners' Grammar Retention', IOSR Journal of Research \& Method in Education (IOSR-JRME) 7, no. 3 (2017): 61-66, https://doi.org/10.9790/73880703026166.

5 Tri Ramadhaniarti, 'Teaching English Vocabulary through Game: Views from the Students', in Proceedings of the Fourth International Seminar on English Language and Teaching (ISELT-4), vol. 4, 2, 2016, 382-87.
}

Furthermore, Sigríour Dögg Sigurðardóttir writes a thesis on the use of games in language classroom. ${ }^{6}$ From his writing, it can be concluded that games should be made as teaching method for the effort to make students more active and to provide them more responsibility as well as to create diversity and that can be very helpful in sustaining interest amongst students in the school that the teachers are reaching out to a broader group of students and that is very important because students are individuals that differ from each other in so many ways. It is also said that games are able to create a comfortable and friendly atmosphere inside the classroom where students, especially shy students, might feel more comfortable in expressing themselves in the target language.

However, this research focuses on the use of games which are prepared and presented by the students within group autonomously. The groups are encouraged to determine and choose any suitable games to present the selected topics in English Syntax classroom. Giving autonomy in the learning provides ample benefits to both teachers and students. It is said that autonomous learning enables to encourage both teachers and students to know and understand one another related to what expected from the

6 Sigríður Dögg Sigurðardóttir, 'The Use of Games in the Language Classroom' (Thesis, Universitatis Islandiae Sigillum, 2010), https://skemman.is/bitstream/1946/6467/1/Sigridu rdogg2010.pdf. 
learning. It is also able to boost the students to be more independent and to be progressively in charge of their learning. Voller in Hernandez states that being autonomous implies having responsibility for making decisions concerning a great deal of aspects of learning: determining objectives, defining contents and progressions, selecting methods and techniques to be used, evaluating what has been learnt and so on. ${ }^{7}$

\section{B. Method}

This study makes use of descriptive research and it is classified into a case study. Bogdan and Biklen ${ }^{8}$ elaborate that a case study is a detailed examination of one setting, or one single depository, or one particular event. ${ }^{9}$ It was conducted at State Islamic Institute of Madura (IAIN Madura) located on JL. Panglegur KM. 04 Pamekasan. The subject research is the $5^{\text {th }}$ semester students of English department who join in English Syntax class. There are 6 classes from $A$ to $F$, however the study is focused on $D$ class which consists of 33 students. The data are gained from

\footnotetext{
7 Emilena Hernandez L., 'Exploring Autonomous Learning Strategies to Deal with the Students' Independent Work in EFL Learning within the Credit System', Revista Actualidades Pedagógicas 48 (2006): 105-12.

8 Bogdan, R.C. \& Biklen, S.K. 1982. Qualitative Research for Education. An Introduction to Theory and Methods.Boston: Allyn \& Bacon. P. 58

9 Robert Bogdan and Sari Knopp Biklen, Qualitative Research for Education: An Introduction to Theory and Methods (Boston: Allyn and Bacon, 1982), 58.
}

classroom observation, questionnaire and interview. The classroom observation was conducted within a semester to gain clear condition of the students during the learning process particularly before and after the middle test sessions.

The questionnaire was given to each student to gain more accurate data related to students' view on the learning English syntax, their response toward the use of the games and their active involvement during the learning process. The data gained from data collection were analysed through three stages namely data reduction, data presentation or display, and data interpretation. In the first stage the data from the observation, interviews and questionnaire were reduced and selected. The relevant data were analysed while the irrelevant data were omitted. In second stage, the researcher presented the data. It was done by identifying, classifying, arranging, and explaining completely, systematically, and objectively. The data obtained were classified to answer the research problems. The findings were displayed in this order: (1) The use of games in making joyful learning, (2) The use of games in increasing the students' active involvement toward the learning. (3) Autonomous learning in helping the students to understand the topics. In the last stage, the researcher elaborates and interprets the data. The result of this study was concluded and presented in the form of specific and brief description. 


\section{Results}

There were 16 meetings of classroom learning activities within a semester. The middle test was conducted in the $8^{\text {th }}$ meeting and the final test was conducted in the $16^{\text {th }}$ meeting. The researcher conducted classroom observation through whole meetings. From the classroom observation, it was derived a clear data that there was a clear distinction between the class sessions before middle test and the sessions after middle test. The class sessions before middle test were handled by the researcher who was teaching in. The learning activities were conducted in the form of interactive lecturing, giving exercises and quizzes.

The learning activities covered three stages-pre activity, whilst activity and post activity. The pre activity covered greeting students, checking attendance list and brain-storming. Whilst activity covered explaining and discussing the topic; Post activity covered making conclusion, asking students to prepare for the next meeting and closing the class session.

The class sessions after middle test were handled by the students which were divided into several groups. The lecturer divided the students into 6 groups-S group, $\mathrm{Y}$ group, $\mathrm{N}$ group, $\mathrm{T}$ group, $A$ group and $X$ group. Each group consisted of 5 to 6 students and given one topic to present. The lecturer gave them autonomy to decide what to do in presenting the topic. The lecturer stated three clear rules for the presentation; first, the learning should be made joyful. Second, it was highly suggested to make use of games for the learning adjusted with the topic being discussed, and the third rule was gaining good comprehension to the material (topic) should be primarily concerned.

In making the presentation joyful, the groups made various efforts to make it came true. Some groups set up the classroom setting such as the position of the chair. They also made use various learning media such as cards, stick, laptop for watching video files and listening to audio files. Even they also brought some candies, snacks for prizes and reward or they just gave them away to each student in the time when they were in boring condition or when the classroom became rather quiet due to less involvement from the students.

In using games, each group ( $S$ to $X$ group) prepared the games to be used in their presentation. The games were varied; they were relay race (conducted by $\mathrm{S}$ group), hidden eyes (conducted by $\mathrm{Y}$ group), music box (conducted by $\mathrm{N}$ group), playing cards (conducted by $\mathrm{T}$ group), Tusuk Sate (Satay Sticks) (conducted by A group), and quiz competition (conducted by $\mathrm{X}$ group).

Relay race the game aimed at training the students' speed in understanding and making tree diagram of English syntax. There were four steps; first, the students are divided into two groups. Second, the two groups were asked to make in line and given a board marker to write on the white 
board. Third, the groups were given a sentence to be analysed and to draw its tree diagram. Fourth, one student from each group only had opportunity to draw one syntactic label and diagram and to be continued by the next student within each group.

Hidden-eyes was a game prepared by $Y$ group. The game was aiming at training the students to give and do the instructions prepared by the group. There were four steps of conducting the game. First, dividing the students into 5 groups consist of 7 students. Second, asking the group to choose the leader asking the leader, whose eyes are covered by cloth, to take any paperbutterfly stuck on the white board where the member of the group lead the leader through giving direction to which paperbutterfly to take. The paper contains a topic/a question (a sentence to be analysed in terms of syntactic label/tree diagram) to discuss. Third, giving the group some minutes to discuss the topic. Fourth, asking every student in the group to write the answer of the question/topic in the condition closing his/her eyes where one of his member of the group gives direction to do it.

Music box is a game which is used to arouse the students' interest and focus on the lesson as well as to make them relaxed. The game is conducted with the following steps. The first step was asking the students to make their sitting position like a half circle. The second step was giving a box to one of student to hold. The third step was playing the music. The fourth was while the music was played on, the student who was holding the box, had to give the box alternately to the friend beside $\mathrm{him} / \mathrm{her}$. The fifth step is stopping the music randomly. The sixth step was the student who held the box when the music stopped was given a question to answer. The question was about the topic being discussed.

Playing card was a game with purposes to make students interested in the topic being discussed and to make them more active as well as to improve their analysis skill. The game was conducted in sections (elimination section and final section). There were nine steps to follow. First, dividing the students into 4 groups; second, determining the leader of the groups; third, asking the leaders to take the card containing some sentences to be discussed and analysed their tree diagram; fourth, asking one representative student of the each group to write the answer on the white board as quick as possible. Fifth, eliminating one group by referring to the most incorrect answer; sixth, continuing to the final section by asking the rest 3 groups to take the card; seventh, giving them 2 minutes to discuss the answer and asking them to write the answer on a piece of paper; eighth, displaying the groups' answer on the white board; and ninth, determining the winner by referring to the most correct answer.

Tusuk sate (satay stick) was a game conducted by using sticks and 
paper-cuts. The sticks were taken from satay sticks. The game aimed at improving students' understanding on doing syntactic analysis and making tree diagram. The steps covered preparing the sticks (satay sticks) and paper-cuts then dividing students into 3 or 4 groups. The next step was giving the groups a sentence to analyse in term of making tree diagram then asking the groups to write the result of their analysis into the paper-cuts pieces by pieces. The following step was asking the groups to put in good order by using the satay sticks. The last step was determining the winner of the game by referring to the fastest group with correct analysis.

Quiz competition ('cerdas cermat') was a game conducted by last group. The game aimed at reviewing the topics having been discussed, arousing students' interest and active involvement and to increase their retention toward the learning. The steps to conduct the game were firstly dividing the class into 4 or 5 groups then asking the groups to make their group's yell. The next step was dividing the game into three sections; they were giving compulsory questions, giving throwing-questions and giving questions with quickest answer. The next step was scoring the game and the last was determining the winner of the game based the highest scores the groups get.

In gaining more data, a questionnaire was distributed to 33 students in the class. There were seven questions to be asked on the questionnaire. The first question was asking the students' opinion on the learning of English syntax whether it was boring or not. The second question was related to the first question on the reasons why the learning of English syntax was boring. If the students' opinion on the learning of English syntax was not boring, so they did not need to answer the second question. There were five options to choose as the reasons; first option was that it was too serious and monotonous activities. The second was there were many formulas to remember and memorize. The third was quiet classroom setting. The fourth option was the learning time at midday or afternoon, and the last option was all options were correct. The third question was asking them whether the use of games enabled to make the learning English syntax joyful. Meanwhile, the fourth question was asking them whether the use of games in the learning of English syntax enabled to increase their active involvement in the learning of English syntax. The fifth question was asking the students' preference on the learning activities before middle test sessions or after middle test sessions. The sixth question was related to the fifth question namely asking the students' reason on their preference whether they preferred the learning sessions before middle test or after middle test. The seventh question was asking the students' opinion on the learning autonomy used in the class 
enable to help them understand more about the topics being discussed or not.

From the questionnaire, the result showed that 26 students (79\%) thought that the learning of English syntax was boring while 7 students (21\%) said that it was not. Related to the second question on the reasons of the boredom of learning English syntax was that 2 students (8\%) chose option A stating that the learning was too serious and monotonous activities, 3 students (11\%) chose option B stating that there were many formula to remember and to memorize, 1 student ( $4 \%$ ) chose option C stating that the classroom setting of the learning English syntax was quiet, 4 students (15\%) chose option D stating that the learning of English syntax became boring due to its learning timeat midday or afternoon, and 16 students $(61 \%)$ chose option $E$ stating that the boredom of the learning of English syntax was caused by all of the options above-too serious and monotonous activities, many formula to remember and memorize, quiet classroom setting and the learning time is at midday or afternoon.

For the fourth question, it was found that 32 students (97\%) agreed to say that the use of games was able to increase their active involvement in the learning activities while 1 student (3\%) disagreed. From the fifth question was found that 30 students (91\%) preferred the learning activities after middle test while 3 students (9\%) preferred the learning activities before middle test.
Meanwhile for the sixth question, it was found that the reasons why the students preferred the learning activities before mid-test because the students were able to get clearer understanding from the lecturer's explanation and the learning became more relax due to having less assignment from lecturer.

Meanwhile, the reasons why the students preferred the learning activities after middle test were more various. They were (a) the classroom learning became more interesting (b) the use of the games made the learning activities more excited (c) working in group was enjoyable (d) making the students more independent (e) the students got more time to make preparation for the learning activities, (f) challenging the students' creativity (g) learning to be teacher/lecturer $(h)$ learning together in group made easier to understand the topic. For the last question which was asking the students' response whether the learning autonomy given to the group enabled to help them understand more about the topics, it was found that 32 students (97\%) agreed that the learning autonomy enabled to give them better understanding to the topics given meanwhile 1 student (3\%) disagreed with it.

\section{Discussion}

The learning process is the result from the interaction of three elementsthe teachers, the students and the subject matters. Those three contribute a reciprocal influence that one may 
support or distract another. ${ }^{10} \mathrm{~A}$ great teacher with great students and great subject matter may make the learning process become great. However, a greater teacher is demanded to make the learning activities become great even though the students and the subject matter are not really great.

To make the learning activities joyful and effective, a teacher or lecturer may make use any various techniques; one of them is by using game. Based on the result from the questionnaire, of the 33 students, 32 students (97\%) agreed the use of the game enabled to make the learning activities joyful that the students felt motivated and enthusiastic in joining the learning activities. Even though the time schedule of the English syntax subject was on midday, the students were active in involving themselves toward the learning. It is in line with Sultanova D.T ${ }^{11}$ stating that using games in grammar class provide a lot of benefits; they are (1) games enable to lower students' anxiety (2) games are highly motivating and entertaining, and they can give shy students more opportunities to express their opinions and feelings (3) they can make students remember things faster and better as long as the games provided in relaxed atmosphere and in

\footnotetext{
10 Gladys Jean and Daphnée Simard, 'Grammar Teaching and Learning in L2: Necessary, but Boring?', Foreign Language Annals 44, no. 3 (September 2011): 467-94, https://doi.org/10.1111/j.1944-9720.2011.01143.x. 11 D.T., 'The Use of Games in Learning English Grammar', 35-36.
}

easy way. In addition, it could be said that the use of games in the English syntax class enabled to encourage the lazy students through boredom become active and enthusiastic and that the boring classroom is able to be decreased.

In presenting the games, the teacher or lecturer may prepare the game well and conduct it in his classroom learning. $\mathrm{He}$ decides everything. He plays a very dominant role in the learning activities. Everything is on his control that the students are only as the recipient of the activities. The lecturer gives clear instruction to his students to ensure the game is well conducted. He directs his students to do what he has planned. The learning is known as teacher (lecturer)-centred learning. In contrast, the lecturer or the teacher lets his students prepare the game. The lecturer may give autonomy to his students to choose and to decide what to do with learning activities by using the game. The students play their role in the learning dominantly and independently. They take their own responsibility to conduct the game well. The lecturer or the teacher is only as the facilitator rather than as the instructor. The learning is known as studentscentred learning.

The teacher-centred learning and the students-centred learning are as the approach used in the learning activities. The two have their own strengths and weaknesses which their main distinction is in who is more dominant in the 
learning - the students or the teachers. In the teacher-centred learning, the teacher decides and chooses what the students will learn, how the students will learn, and how the students will be assessed on their learning meanwhile in student-centred learning requires students to be active, responsible participants in their own learning and with their own pace of learning. ${ }^{12}$

Another strength and weakness of teacher-centred and student-centred learning are that teacher-centred learning is more suitable for large class, learning materials can be well prepared, teacher may feel less nervous, it takes shorter time to do the class activities and all he will do is transferring the knowledge. However, the students will be passive and it will lead them to be more competitive and individualistic because they have less opportunity to get involved in the learning more over if the teacher uses monotonous learning strategies. Meanwhile, in the studentcentred learning, the students get challenged to be more active and decide what they really need as long as they explore their knowledge. The learning becomes flexible, experiential and selfdirected. Since the teacher is the facilitator, so what the teachers have to do is considering the needs of the students, as a group and as individuals,

12 M. M. Tursunov, 'A Comparative Analysis of Teacher-Centered And Learner-Centered Classes', Международный Научный Журнал 6, no. 3 (2016), http://irbis-nbuv.gov.ua/cgibin/irbisnbuv/cgiirbis. and encouraging them to participate in the learning process all the time. ${ }^{13}$

The teaching of English syntax for the $5^{\text {th }}$ semester students of English department IAIN Madura makes use the combination of teacher-centred learning and student-centred learning. The learning activities before middle test use teacher-centred learning and the learning activities after middle test use student-centred learning. However, from the result of the questionnaire, it could be clearly stated that most of the students (30 students or $91 \%$ students) prefer the learning activities after middle test which mean that the students feel more comfortable toward the studentcentred learning.

The student-centred learning is the replacement of teacher-centred learning which is known as traditional approach of learning. It is said that teacher-centred learning actually prevents students' educational growth. ${ }^{14}$ Meanwhile, student-centred learning is most suitable for the more autonomous, and more selfdirected learners who not only participate in what, how, and when to learn, but also construct their own learning experience. The students are

\footnotetext{
13 Ive Ameliana, 'Teacher-Centered or StudentCentered Learning Approach to Promote Learning?', Jurnal Sosial Humaniora 10, no. 2 (30 November 2017): 59-70, https://doi.org/10.12962/j24433527.v10i2.2161.

14 Maryam Lak, Hassan Soleimani, and Farid Parvaneh, 'The Effect of Teacher-Centeredness Method vs. Learner-Centeredness Method on Reading Comprehension among Iranian EFL Learners', Journal of Advances in English Language Teaching 5, no. 1 (2017): 1-10.
} 
learning by doing and experiencing rather than depending on the teachers' wisdom and expertise to transmit knowledge. ${ }^{15}$

Encouraging students to be independent and autonomous in learning is highly suggested to conduct toward the students particularly to college students. It trains them to be more mature in decision-making toward their learning. By giving them autonomy, they will be challenged to make their own classroom learning become more joyful and surely they will be more active in involving themselves in the learning activities. The data from questionnaire shows that 32 students (97\%) agreed with the learning autonomy given to them because it can help them to get better understanding toward the lesson. Autonomous learning enables to give them a by-doing learning and experiential learning. Besides, it is also able to challenge their creativity particularly in preparing the games for learning in English syntax classroom.

Autonomous learning in studentcentred learning is able to be set in individual, in pair or in a group. ${ }^{16}$ When the student works alone, he/she may prepare ideas or make some notes before a class discussion and do individual task or grammar exercise. When the students work in pair or in groups, they may compare and discuss or share their ideas, opinions and

15 Lak, Soleimani, and Parvaneh, 2.

16 Tursunov, 'A Comparative Analysis of TeacherCentered And Learner-Centered Classes', 66. experiences. It is also possible to set a teacher-led: before the students work together, the teacher is available to give help to the students by giving them general rules for the task to be conducted, giving them advice and encouragement. After the students finished working together, the teacher may give them feedback, offer suggestion, make correction and help answering the questions.

The autonomous learning conducted in the learning of English syntax in D class IAIN Madura is set in the form of teacher/lecturer-led. It was conducted by firstly grouping the students into 6 groups which were named as $\mathrm{S}$ group, $\mathrm{Y}$ group, $\mathrm{N}$ group, $\mathrm{T}$ group, $A$ group and $X$ group. To make the learning activities under control, the lecturer gave three most important rules during the learning activities (1) The learning should be made joyful, (2) It was highly suggested to make use of games for the learning adjusted with the topic being discussed, and (3) Gaining good comprehension to the material (topic) should be primarily concerned.

\section{Conclusion}

The learning of English syntax is taken as boring subject for its monotonous activities, memorizing grammar rules, serious and quiet classroom activities, and midday or afternoon learning time. As the teacher or lecturer of English syntax, it is a challenge to lose the students' boredom by providing a joyful learning and 
encouraging their active involvement toward the learning. The use of games in classroom instruction has been proven to create a joyful learning because of its ample benefits. However, it is more joyful and exciting when the games and learning activities are provided by the students autonomously. Giving a learning autonomy to the students is able to encourage the students' selfdirected learning, increase their creativity and surely improve their active involvement toward the learning activities as well as increase their understanding to the lessons because they are learning by doing.

\section{Reference}

Ameliana, Ive. 'Teacher-Centered or Student-Centered Learning Approach to Promote Learning?' Jurnal Sosial Humaniora 10, no. 2 (30 November 2017): 59-70. https://doi.org/10.12962/j244335 27.v10i2.2161.

Bogdan, Robert, and Sari Knopp Biklen. Qualitative Research for Education: An Introduction to Theory and Methods. Boston: Allyn and Bacon, 1982.

D.T., Sultanova. 'The Use of Games in Learning English Grammar'. In Proceeding of Uzbek-Indonesian Joint International Conference, Vol. 1. Gunadarma University, 2011.

https://core.ac.uk/download/pdf/1 43964197.pdf.
Dwiaryanti, Risca. 'Learning Vocabulary through Colourful Puzzle Game'. OKARA: Jurnal Bahasa Dan Sastra 8, no. 1 (2014): 10.

Jean, Gladys, and Daphnée Simard. 'Grammar Teaching and Learning in L2: Necessary, but Boring?' Foreign Language Annals 44, no. 3 (September 2011): 467-94. https://doi.org/10.1111/j.19449720.2011.01143.x.

L., Emilena Hernandez. 'Exploring Autonomous Learning Strategies to Deal with the Students' Independent Work in EFL Learning within the Credit System'. Revista Actualidades Pedagógicas 48 (2006): 105-12.

Lak, Maryam, Hassan Soleimani, and Farid Parvaneh. 'The Effect of Teacher-Centeredness Method vs. Learner-Centeredness Method on Reading Comprehension among Iranian EFL Learners'. Journal of Advances in English Language Teaching 5, no. 1 (2017): 1-10.

O'Grady, William, and Michael Dobrovolsky. Contemporary Linguistics: An Introduction. New York: St. Martin's Press, 1989.

Phuong, Hoang Yen, and Thao Nguyen Pham Nguyen. 'The Impact of Board Games on EFL Learners' Grammar Retention'. IOSR Journal of Research \& Method in Education (IOSR-JRME) 7, no. 3 (2017): 61-66. https://doi.org/10.9790/73880703026166. 
Ramadhaniarti, Tri. 'Teaching English Vocabulary through Game: Views from the Students'. In Proceedings of the Fourth International Seminar on English Language and Teaching (ISELT4), 4:382-87. 2, 2016.

Sigurðardóttir, Sigríður Dögg. 'The Use of Games in the Language Classroom'. Thesis, Universitatis Islandiae Sigillum, 2010. https://skemman.is/bitstream/194 6/6467/1/Sigridurdogg2010.pdf.

Tursunov, M. M. 'A Comparative Analysis of Teacher-Centered And Learner-Centered Classes'. Международный Научный Журнал 6, no. 3 (2016). http://irbis-nbuv.gov.ua/cgibin/irbisnbuv/cgiirbis. 
Appendix

The pictures of satay stick game
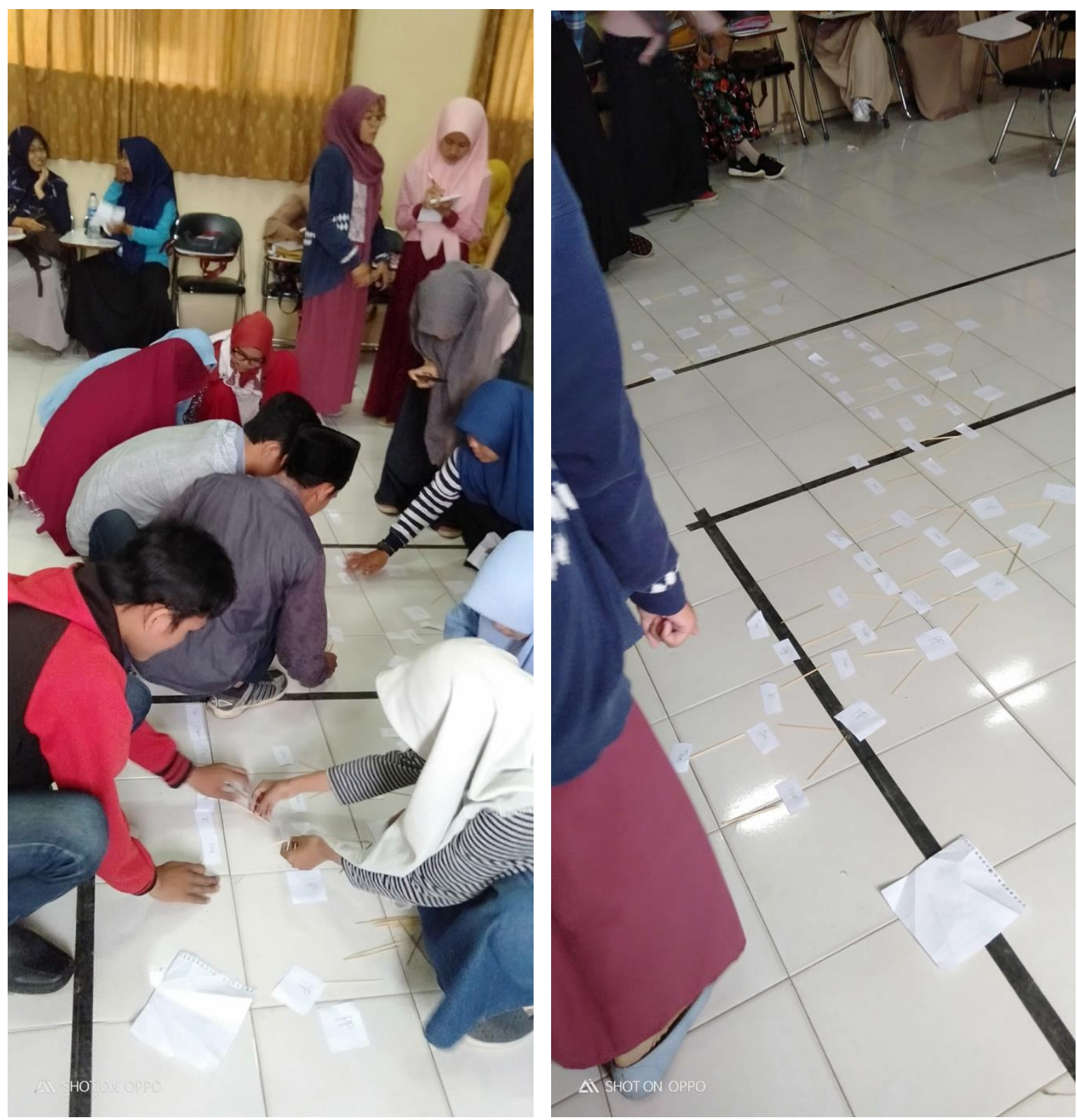